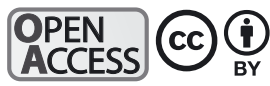

\section{Top-down control by micro- and mesozooplankton on winter dinoflagellate blooms of Heterocapsa rotundata}

\author{
N. C. Millette*, D. K. Stoecker, J. J. Pierson \\ Horn Point Laboratory, University of Maryland Center for Environmental Science (UMCES), PO Box 775, Cambridge, \\ MD 21613, USA
}

\begin{abstract}
Winter dinoflagellate blooms in Chesapeake Bay tributaries can account for over $50 \%$ of a system's annual primary production, potentially more than the spring diatom bloom. Research on winter blooms has focused on environmental conditions that result in blooms, but little focus has been given to the potential importance of zooplankton grazers. We investigated the impact of microzooplankton and mesozooplankton (copepods) grazing on the population of winter phytoflagellates in the Choptank River, MD, in 2012 to 2013 and 2013 to 2014 . We estimated community microzooplankton and copepod grazing rates on the dominant phytoflagellate species, and measured daily gross primary production (GPP) rates. The chlorophyll a concentration and the abundance of the dinoflagellate Heterocapsa rotundata were significantly higher in 2013 to 2014 compared with 2012 to 2013, but average daily GPP was similar between the 2 yr. However, the average percentage of daily GPP removed by grazers in 2013 to 2014 was lower than in 2012 to 2013, despite average environmental conditions and nutrient concentrations not differing between years. We hypothesize that the observed release from grazing pressure is one of the main factors controlling winter dinoflagellate bloom formation in these and other coastal temperate systems.
\end{abstract}

KEY WORDS: Winter · Dinoflagellate blooms · Predator-prey · Top-down · Chesapeake Bay · Copepod · Grazing

\section{INTRODUCTION}

In estuaries, dinoflagellates are known to form winter blooms (Sellner et al. 1991, Litaker et al. 2002a, Marshall et al. 2005), but winter is generally under-sampled and the aquatic food-web dynamics during this time are poorly understood. Winter productivity is commonly assumed to be low compared with the remainder of the year, and this period is not often the focus of research. However, Litaker et al. (2002a) and Sellner et al. (1991) have suggested that winter blooms of dinoflagellate species Heterocapsa triquetra and Heterocapsa rotundata, respectively, can account for $\sim 50 \%$ of annual phytoplankton car-

\footnotetext{
*Corresponding author: millette@umces.edu
}

bon production within an estuary, suggesting an important role for such blooms in the annual productivity of estuarine systems.

Past research on winter dinoflagellate blooms on the east coast of the United States has focused on the physical changes to the environment that initiate blooms (Cohen 1985, Sellner et al. 1991, Litaker et al. 2002b). High rainfall and increased river flow have been shown to trigger such blooms by creating a stratified water column (Cohen 1985) and causing a large influx of nutrients (Litaker et al. 2002b). However, few studies have addressed the influence of zooplankton grazers on the formation and maintenance of winter dinoflagellate blooms. Studies have

() The authors 2015. Open Access under Creative Commons by Attribution Licence. Use, distribution and reproduction are unrestricted. Authors and original publication must be credited. 
explored the role of grazing on the decline of these blooms. Sellner et al. (1991) calculated that the copepod Eurytemora carolleeae (cf. E. affinis, Alekseev \& Souissi 2011) removed $67 \%$ of the daily biomass through grazing at the height of a $H$. rotundata bloom in the Patuxent River, a tributary of Chesapeake Bay, MD, and postulated that grazing controlled the dissipation of the bloom. Litaker et al. (2002a) estimated that at peak winter abundance, the copepod Acartia tonsa removed only $\sim 1 \%$ of $H$. triquetra standing stock during a bloom in the Newport River estuary, NC. However, in both studies, the initiation of the bloom was attributed to bottom-up forcing based on river flow.

In the past decade, the role of reduced grazing pressure in phytoplankton bloom formation, specifically from microzooplankton, has gained acceptance (Irigoien et al. 2005, Stoecker et al. 2008). Irigoien et al. (2005) suggest that physical or chemical perturbations can break down strong predator-prey links in 'mature systems' to allow a 'loophole' that phytoplankton can exploit to form a bloom. Stoecker et al. (2008) suggest that in Chesapeake Bay, eutrophication caused by land run-off can result in trophic cascades that produce negative feedback to microzooplankton grazing pressure, and a 'window of opportunity' opens that allows small dinoflagellates to bloom.

Winters with high rainfall create optimum conditions for blooms (Cohen 1985, Sellner et al. 1991, Litaker et al. 2002a), and we focused our research on understanding how grazers impact and/or control winter dinoflagellate blooms. The removal of dinoflagellates by grazing can serve as an important top-down control on winter blooms. Therefore, we hypothesized that a reduction in zooplankton grazing rates is required for an increase in $H$. rotundata abundance. Reduced grazing pressure allows a bloom to form, whereas increased grazing pressure leads to the collapse of the bloom (Irigoien et al. 2005). To test this hypothesis, we measured phytoflagellate, microzooplankton, and mesozooplankton abundances and the grazing rates of both zooplankton groups on the dominant microplankton in the winters of 2012 to 2013 and 2013 to 2014 in the Choptank River, a tributary of Chesapeake Bay. Winters 2012 to 2013 and 2013 to 2014 will be referred to as winter 2013 and winter 2014, respectively. We also compared the environmental conditions from the $2 \mathrm{yr}$ to confirm that relaxation in topdown controls was important to winter bloom formation, and that winter bloom formation was not driven by environmental conditions.

\section{MATERIALS AND METHODS}

\author{
Setting and sampling
}

We collected water weekly from 23 December 2012 to 10 March 2013 and 30 December 2013 to 10 March 2014 from a fishing pier on the Choptank River in Cambridge, MD, USA (383 $\left.34^{\prime} 24^{\prime \prime} \mathrm{N}, 76^{\circ} 4^{\prime} 6^{\prime \prime} \mathrm{W}\right)$. The Choptank River is a tributary that feeds into the mesohaline section of the Chesapeake Bay. Each week we collected 30 to 40 l surface water with a bucket and immediately filtered it through $200 \mu \mathrm{m}$ mesh to remove larger plankton. We then conducted 2 vertical net tows to collect mesozooplankton samples with a plankton ring net fitted with $200 \mu \mathrm{m}$ mesh. One tow sample was immediately preserved in $4 \%$ formalin, while the sample from the other tow was decanted into glass jars and kept alive to be sorted for copepods used in grazing experiments on return to the laboratory. Temperature and salinity were measured with a handheld YSI-30 conductivity and temperature meter immediately after the bucket was retrieved. Samples for nutrients (dissolved nitrate + nitrite, ammonium, and phosphorus) were filtered through a Whatman $0.45 \mu$ m nylon sieve with glass microfiber (model number 4552) and immediately frozen for subsequent analysis at Horn Point Laboratory Analytical Services. Water and plankton for grazing and primary production experiments were transported to UMCES Horn Point Laboratory in Cambridge, MD, and maintained in an incubator at ambient water temperature until all experiments were set up, always within $3 \mathrm{~h}$ of sample collection.

\section{Primary production}

Each week we incubated six $30 \mathrm{ml}$ glass vials of unfiltered seawater ( 3 light, 3 dark) for $24 \mathrm{~h}$ to estimate the primary production rate using the oxygen evolution method (Howarth \& Michaels 2000), similar to recent winter research in the Chesapeake Bay (Lee et al. 2012). The vials were placed in mesh bags that allowed in $55 \%$ of natural light, and incubated in floats in a small, protected cove of the Choptank River. Gross primary production was quantified from the change in dissolved $\mathrm{O}_{2}$ in the light and dark bottles. Samples were analyzed with a mass spectrometer to measure $\mathrm{O}_{2}$ :Ar ratio; argon is an unreactive noble gas, therefore a change in the dissolved $\mathrm{O}_{2}$ :Ar ratio between the initial and final samples is assumed to be the result of changes in $\mathrm{O}_{2}$ and not Ar (Kana et al. 1994). The coefficient of variation for the membrane 
inlet mass spectrometer is $<0.5 \%$ for $\mathrm{O}_{2}$ and $<0.05 \%$ for $\mathrm{O}_{2}$ :Ar ratio (Kana et al. 1994). We converted the change in $\mathrm{O}_{2}$ concentration to carbon, assuming that for every mole of carbon fixed, 1 mole of $\mathrm{O}_{2}$ is produced (Howarth \& Michaels 2000). We then converted the change in carbon concentration $(\mu \mathrm{M} \mathrm{C})$ over time to change in biomass per unit volume over time, to estimate primary production $\left(\mathrm{g} \mathrm{C} \mathrm{m}^{-3} \mathrm{~d}^{-1}\right)$ at the surface at our sample site.

\section{Microzooplankton grazing}

Dilution experiments, as described by Landry \& Hassett (1982), were used to measure community grazing coefficients $\left(\mathrm{d}^{-1}\right)$ for microzooplankton on phytoflagellates and intrinsic phytoflagellate growth rate $\left(\mathrm{d}^{-1}\right)$. The filtered water for the dilution experiments was made using a $0.2 \mu \mathrm{m}$ pleated filter in a capsule from Life Sciences (model number FW3846). Triplicate $1 \mathrm{l}$ bottles were used for each of 4 treatments: $100,20,10$, and $5 \%$ whole water. These dilution treatments were chosen because the higher the proportion of filtered water, the greater the decoupling between microzooplankton grazing and phytoflagellate growth, due to the reduced microzooplankton grazing pressure in diluted water (Landry \& Hassett 1982).

Each week we estimated the microzooplankton grazing coefficient on phytoplankton biomass and on the dominant phytoflagellate species/groups: Heterocapsa rotundata (a dinoflagellate), and cryptophytes. Dominant phytoflagellates were defined as $\geq 25 \%$ of the $>10 \mu \mathrm{m}$ phytoflagellate community. $H$. rotundata, a dominant species, and cryptophytes, a dominant group, were the only ones to fit this description (Table 1). Diatoms were present at abundances of between 250 and 3500 cells ml $^{-1}$ (data not shown), but were not included in analysis because of the focus on phytoflagellates.

As a proxy for phytoplankton biomass, we measured chlorophyll a from all the dilution bottles at the start and end of our experiments. Three samples from

Table 1. Average percentage $( \pm \mathrm{SD})$ of the total $>10 \mu \mathrm{m}$ phytoflagellate community that Heterocapsa rotundata, cryptophytes, Prorocentrum minimum, and Heterocapsa triquetra accounted for in the winters of 2013 and 2014

\begin{tabular}{|lcccc|}
\hline Year & $\begin{array}{c}\text { H. rotundata } \\
(\%)\end{array}$ & $\begin{array}{c}\text { Cryptophytes } \\
(\%)\end{array}$ & $\begin{array}{c}\text { P. minimum } \\
(\%)\end{array}$ & $\begin{array}{c}\text { H. triquetra } \\
(\%)\end{array}$ \\
\hline $2012-2013$ & $34.99 \pm 10.25$ & $59.23 \pm 12.47$ & $5.23 \pm 7.81$ & $0.55 \pm 0.98$ \\
$2013-2014$ & $72.79 \pm 20.95$ & $25.19 \pm 18.08$ & $0.77 \pm 1.48$ & $1.25 \pm 2.66$ \\
\hline
\end{tabular}

each initial treatment bottle and 1 sample from each triplicate bottle at the end of the experiment, whole seawater and dilutions, were filtered onto $25 \mathrm{~mm}$ GF/F glassfiber filters and extracted in $90 \%$ acetone for $24 \mathrm{~h}$ in the freezer (Arar \& Collins 1997). The chlorophyll fluorescence of the acetone extract was measured with a Turner Designs AU-10 fluorometer. To determine $>10 \mu \mathrm{m}$ phytoflagellate species and abundances, we preserved 10 to $12 \mathrm{ml}$ from each bottle in acid Lugol's solution. Samples were counted and identified with a Nikon Eclipse E800 microscope at 20x magnification on a Sedgewick rafter slide (Sherr \& Sherr 1993). A minimum of 300 cells were counted per sample. Chlorophyll a concentrations and abundances of phytoflagellates in the initial $100 \%$ whole water bottles were used to estimate in situ concentrations in the surface water.

We used the equation for exponential growth to estimate the apparent growth rate of the phytoplankton biomass, $H$. rotundata, and cryptophytes at each dilution (Landry \& Hassett 1982). To eliminate the potential to have non-linear regression curves in the dilution experiments caused by non-limiting concentrations of prey, we used the 2-point dilution method to estimate the microzooplankton community grazing coefficient $(g)$ and the apparent phytoplankton growth rate $(\mu)$ (Worden \& Binder 2003). The estimated phytoflagellate growth rate at $5 \%$ whole water was used to calculate $\mu$, and the difference between the estimated phytoflagellate growth rate at 100 and $5 \%$ whole water was used to calculate $g$. The 2-point dilution method provides a conservative estimation of $\mu$ and $g$ (Worden \& Binder 2003). We calculated the ingestion rate of $H$. rotundata and cryptophytes by the microzooplankton community according to Strom et al. (2001).

Chlorophyll a concentrations and species abundances were both converted to carbon for comparison. Living algal carbon $\left(\mu \mathrm{g} \mathrm{l}^{-1}\right)$ was estimated using the conversion of $50 \times$ chlorophyll a (Strickland 1965). The average cell volume for individual species was determined by measuring the length and diameter of 30 individual organisms using a calibrated ocular micrometer, and cell volumes were estimated from the equation for a rotational ellipsoid: volume $=(\pi \div 6) \times$ diameter ${ }^{2} \times$ height. The volume of an individual $H$. rotundata and of a cryptophyte cell was converted to carbon using the equation for dinoflagellates and the equation for other plankton excluding diatoms, respectively (Menden-Deuer \& Lessard 2000). 


\section{Mesozooplankton grazing}

To estimate mesozooplankton grazing, we used prey removal experiments. Two triplicate sets of 11 containers with $200 \mu \mathrm{m}$ filtered water were incubated along with the dilutions experiments. One set was enriched with 10 to 20 copepods from the vertical tows and 1 set was without copepods. We used the copepod Eurytemora carolleeae because it is the dominant species in the estuary in winter (Kimmel et al. 2006) and also dominant in our mesozooplankton samples. Another copepod, Acartia tonsa, was present early in the time series in both years and a few individuals may have inadvertently been included in our experiments, despite our best efforts to pick only E. carolleeae. We chose larger copepods (a mixture of copepodites and adults) with both of their antennae intact for each experiment.

We calculated the change in chlorophyll a biomass and abundances of $H$. rotundata and cryptophytes over the duration of the experiments ( $24 \mathrm{~h}$ ) for each of the bottles in the experiment each week. At the end of each experiment, the live copepods in each bottle were counted and this number was used to calculate the per capita clearance $\left(\mathrm{ml}\right.$ copepod $\left.^{-1} \mathrm{~d}^{-1}\right)$ and ingestion rates (cells copepod ${ }^{-1} \mathrm{~d}^{-1}$ ) according to calculations from Frost (1972). The percentage prey standing stock removed by copepods $\left(S S_{\mathrm{r}}, \mathrm{d}^{-1}\right)$ in the surface water was estimated as:

$$
S S_{\mathrm{r}}=\left(\left[I \times A_{\mathrm{c}}\right] \div A_{\mathrm{p}}\right) \times 100
$$

where $I$ is the ingestion rate of an individual copepod, $A_{\mathrm{c}}$ is the abundance of copepods in the water column (copepods $\mathrm{l}^{-1}$ ), and $A_{\mathrm{p}}$ is the abundance of the prey in the water column (cells $1^{-1}$ ).

We counted a minimum of 200 copepods from a subsample of the preserved sample to estimate in situ abundances. The sample was counted with a dissecting microscope at $2 \times$ magnification on a gridded petri dish. We combined E. carolleeae and A. tonsa abundances to estimate total copepod abundance, but in general E. carolleeae accounted for $81 \%$ of all copepods counted. There were only 3 weeks when $E$. carolleeae accounted for $<50 \%$ of the copepod population and those weeks were at the start of the winter seasons when copepod abundances were low (data not shown). No attempt was made to separate the different copepodite stages. In the third week of winter 2013 our sample of copepods to estimate in situ abundances was lost, and we estimated copepod abundance for that week as the average of copepod abundance from the 2 previous and 2 subsequent weeks $\left(7.25 \pm 4.9\right.$ copepods $\left.\mathrm{l}^{-1}, \mathrm{~N}=4\right)$.
Most of the prominent phytoflagellate prey items measuring $>10 \mu \mathrm{m}$ were identified to the species level, including $H$. rotundata, Heterocapsa triquetra, and Prorocentrum minimum. Diatoms had low abundances and were counted as a group. Microzooplankton abundances were pooled from abundances of non-loricate ciliates, tintinnids, and heterotrophic dinoflagellates; our experiments could only estimate the community grazing coefficient of microzooplankton, not grazing by individual taxa.

\section{Data analysis}

Similar to findings in previous studies (Worden \& Binder 2003, Strom \& Fredrickson 2008), there was not a significant difference between our analysis of dilution experiments using the 2-point method and the standard linear regression method, based on paired $t$-tests $(\mathrm{p}=0.857(\mu)$ and $\mathrm{p}=0.952(g)$ for H. rotundata; $\mathrm{p}=0.402(\mu)$ and $\mathrm{p}=0.249(\mathrm{~g})$ for cryptophytes). Therefore, all subsequent data manipulation was done based on the data from the 2-point method. A paired $t$-test was used to compare the estimated growth rate of phytoplankton (chlorophyll $a$ concentration) or growth rates of individual target phytoplankton taxa (abundances of $H$. rotundata and cryptophytes) between the 100 and $5 \%$ whole water treatments. The microzooplankton community grazing coefficient was considered significantly different from 0 for each experiment at $p<0.05$ for these analyses. A 1-sample $t$-test was used to determine whether copepod ingestion rates were significantly different from $0(\mathrm{p}<0.05)$. Any negative grazing values were changed to 0 for subsequent analysis of amount or proportion of standing stocks removed by grazers (Strom et al 2001). Seventeen of 46 copepod grazing rates and 18 of 46 microzooplankton community grazing rates were changed to 0 .

We used 2-sample equal variance $t$-tests to determine statistically significant differences $(p<0.05)$ between our 2 sampling years. All of our averaged values are presented \pm SD throughout the results.

\section{RESULTS}

\section{Environmental conditions and standing stocks}

The average water temperature in winter 2013 $\left(4.2 \pm 1.4^{\circ} \mathrm{C}\right)$ was not significantly different from that in winter $2014\left(3.0 \pm 2.0^{\circ} \mathrm{C}\right)$ (2-sample $t$-test, $\mathrm{p}=$ 0.103; Fig. 1). Between Weeks 5 and 7 in 2014, the 

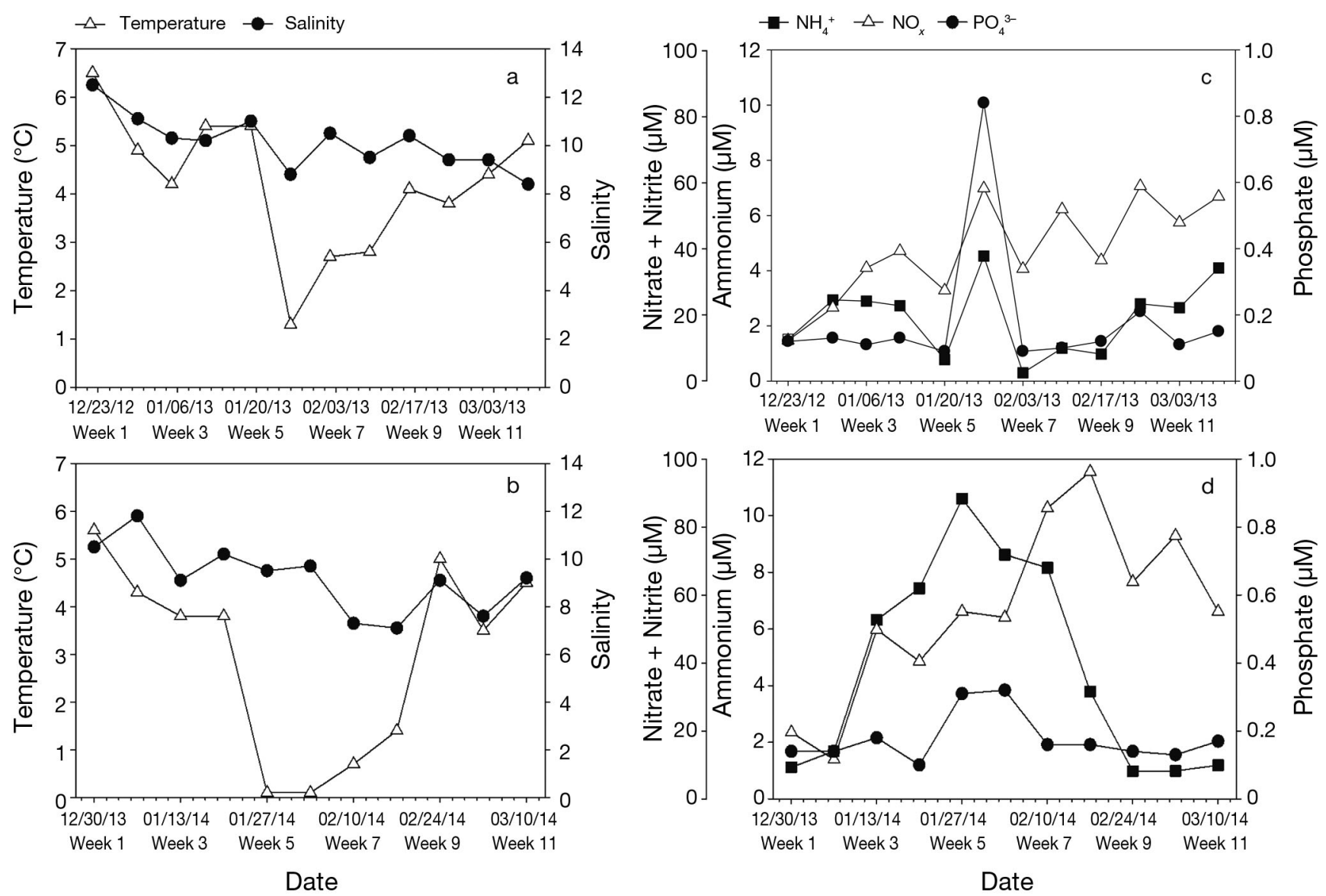

Fig. 1. (a,b) Water temperature $\left({ }^{\circ} \mathrm{C}\right)$ and salinity in the Choptank River, MD, in the winters of (a) 2013 and (b) $2014 .(\mathrm{c}, \mathrm{d})$ Ammonium, nitrate + nitrite, and phosphate concentration in the Choptank River in the winters of (c) 2013 and (d) 2014 . Dates given as $\mathrm{mm} / \mathrm{dd} / \mathrm{yy}$

water temperature was below $1.0^{\circ} \mathrm{C}$ and the river was ice-covered (Fig. 1). In 2013, the minimum water temperature was $1.9^{\circ} \mathrm{C}$. Salinity in winter 2013 was not significantly different from winter $2014(\mathrm{p}=$ $0.093)$, averaging $10.1 \pm 1.1$ in 2013 and $9.1 \pm 1.4$ in 2014 (Fig. 1). There was little variation in salinity from week to week in both winters (Fig. 1a,b).

The average nitrate + nitrite, ammonium, and phosphate concentrations were not significantly different from each other between the 2 winters $(p=$ $0.09, p=0.05$, and $p=0.93$, respectively), and concentrations ranged from 0 to $100 \mu \mathrm{M}$ for nitrate + nitrite $\left(\mathrm{NO}_{\mathrm{x}}\right)$, from 0 to $10 \mu \mathrm{M}$ for ammonium $\left(\mathrm{NH}_{4}{ }^{+}\right)$, and from 0 to $1 \mu \mathrm{M}$ for phosphate $\left(\mathrm{PO}_{4}{ }^{3-}\right)$ in the winter (Fig. 1C,d). The average nutrient concentrations were $39.87 \pm 15.00 \mu \mathrm{M}$ of $\mathrm{NO}_{\mathrm{x}}, 2.29 \pm$ $1.33 \mu \mathrm{M}$ of $\mathrm{NH}_{4}{ }^{+}$, and $0.18 \pm 0.21 \mu \mathrm{M}$ of $\mathrm{PO}_{4}{ }^{3-}$ (Fig. 1C) in winter 2013. In winter 2014, the average nutrient concentrations were $55.27 \pm 25.66 \mu \mathrm{M}$ of $\mathrm{NO}_{\mathrm{x}}, 4.63 \pm 3.67 \mu \mathrm{M}$ of $\mathrm{NH}_{4}{ }^{+}$, and $0.18 \pm 0.07 \mu \mathrm{M}$ of $\mathrm{PO}_{4}{ }^{3-}$ (Fig. 1d). The SDs for equipment used by
Analytical Services are $<0.1 \mu \mathrm{M}$ for $\mathrm{NO}_{\mathrm{x}}$ and $\mathrm{PO}_{4}{ }^{3-}$, and $0.06 \mu \mathrm{M}$ for $\mathrm{NH}_{4}{ }^{+}$.

We defined 'bloom' abundances as $>10000{\text { cells } 1^{-1}}^{-1}$ for both Heterocapsa rotundata and cryptophytes, or chlorophyll a concentrations $>45 \mu \mathrm{g} \mathrm{l^{-1 }}$, and using these criteria there was no winter bloom at our station in the Choptank River in winter 2013. Total chlorophyll a concentrations averaged $20.5 \pm 6.4 \mu \mathrm{g}$ $\mathrm{l}^{-1}, H$. rotundata averaged $1330 \pm 970$ cells ml $^{-1}$, and cryptophytes averaged $2125 \pm 1032$ cells ml ${ }^{-1}$. For all but 1 wk (Week 3), cryptophytes were the dominant group of $>10 \mu \mathrm{m}$ phytoflagellates (Fig. 2a). From January to the middle of March 2013, $H$. rotundata and cryptophytes accounted for an estimated $50 \%$ of the total phytoplankton carbon each week (Fig. 2a). Heterocapsa triquetra and Prorocentrum minimum were present only in background concentrations (Table 2).

In winter 2014, a H. rotundata bloom occurred in the last $3 \mathrm{wk}$ of sampling. Total chlorophyll a concentrations averaged $27 \pm 21.1 \mathrm{\mu g} \mathrm{l}^{-1}, H$. rotundata averaged $7236 \pm 7731 \mathrm{cells} \mathrm{ml}^{-1}$, and cryptophytes 

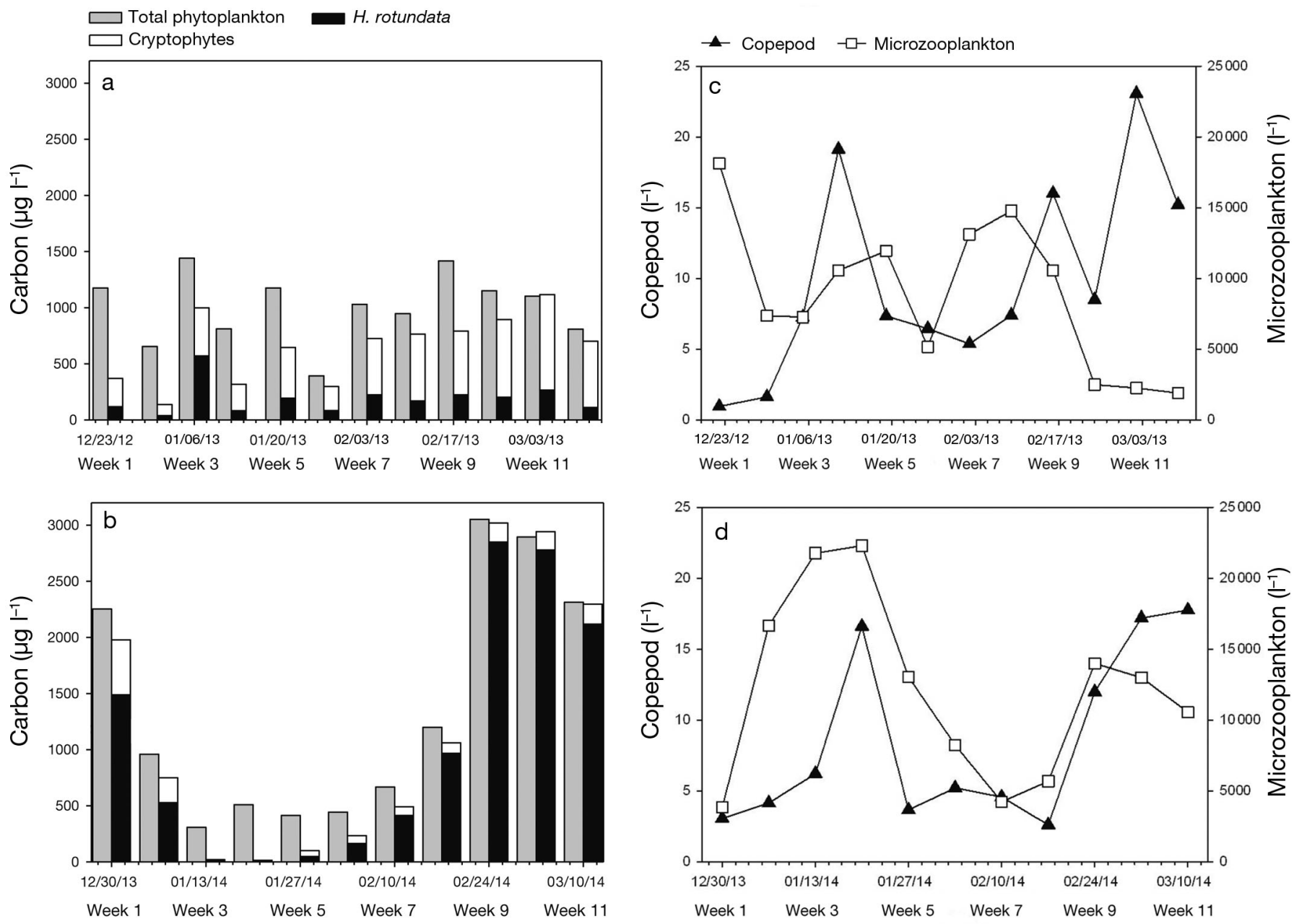

Date

Date

Fig. 2. $(\mathrm{a}, \mathrm{b})$ Estimated carbon content of total phytoplankton based on chlorophyll a, Heterocapsa rotundata, and cryptophytes in surface waters of the Choptank River, MD, in the winters of (a) 2013 and (b) 2014. (c,d) Estimated abundance of the copepod Eurytemora carolleeae + Acartia tonsa and microzooplankton in surface waters of the Choptank River in the winters of (c) 2013 and (d) 2014. Dates given as $\mathrm{mm} / \mathrm{dd} / \mathrm{yy}$

averaged $993 \pm 968$ cells $\mathrm{ml}^{-1}$. H. rotundata accounted for an estimated $54 \%$ and cryptophytes for an estimated $11 \%$ of the total phytoplankton carbon (Fig. 2b). In the last 4 wk of sampling in $2014, H$. rotundata accounted for over $80 \%$ of the estimated phytoplankton carbon (Fig. 2b). Abundances of $H$. rotundata and cryptophytes were initially 10431 and 3483 cells ml $^{-1}$, respectively, but abundances of both taxa declined to $<100$ cells $\mathrm{ml}^{-1}$ by Week 3 (Fig. 2b). Starting in Week 4, $H$. rotundata grew exponentially each week until they reached 19942 cells ml $^{-1}$ in Week 9 (Fig. 2b). Cryptophyte abundance grew to 1208 cells $\mathrm{m}^{-1}$ in Week 9 (Fig. 2b). In Week 9, chlorophyll a reached $61 \mathrm{\mu g} \mathrm{l}^{-1}$. Similar to 2013, H. triquetra and P. minimum were present only in background concentrations (Table 2).
There was no difference in the mean abundance of copepods (adults and copepodites of Eurytemora carolleeae and Acartia tonsa) between the 2 years (2-sample $t$-test, $\mathrm{p}=0.615)$. Abundance averaged $10 \pm 7 \mathrm{l}^{-1}$ in 2013 and $8 \pm 6 \mathrm{l}^{-1}$ in 2014 (Fig. 2d). Mean abundance of microzooplankton was $8781 \pm 5268$ cells $l^{-1}$ in 2013 and $12111 \pm 6400$ cells l$^{-1}$ in 2014 , with no difference between the 2 years (2-sample $t$-test, $\mathrm{p}=0.187$; Fig. 2d).

\section{Proportion of Heterocapsa rotundata and cryptophytes consumed}

We estimated the percentage standing stock for each species/group that was removed by each type of grazer to quantify the impact grazers had on the 
Table 2. Comparison of the concentration of Heterocapsa rotundata and cryptophyte carbon $\left(\mathrm{l}^{-1}\right)$ removed by copepods and microzooplankton through grazing in the winters of 2013 and 2014. Average values are shown \pm SD. Dates given as $\mathrm{mm} / \mathrm{dd} / \mathrm{yy}$. Values in bold are based on grazing rates that are statistically different from $0(p<0.05)$

\begin{tabular}{|c|c|c|c|c|}
\hline \multirow[t]{2}{*}{ Date } & \multicolumn{2}{|c|}{$-H$. rotundata -} & \multicolumn{2}{|c|}{ - Cryptophytes } \\
\hline & $\begin{array}{l}\text { Copepod } \\
\left(\mu \mathrm{g} \mathrm{C}^{-1}\right)\end{array}$ & $\begin{array}{l}\text { Microzooplankton } \\
\quad\left(\mu \mathrm{g} \mathrm{C}^{-1}\right)\end{array}$ & $\begin{array}{l}\text { Copepod } \\
\left(\mu \mathrm{C} \mathrm{Cl}^{-1}\right)\end{array}$ & $\begin{array}{l}\text { Microzooplankton } \\
\qquad\left(\mu \mathrm{g} \mathrm{C} \mathrm{l}^{-1}\right)\end{array}$ \\
\hline $12 / 23 / 12$ & 0.70 & 129.94 & 4.61 & 46.17 \\
\hline $12 / 31 / 12$ & 0 & 33.16 & 0 & 26.30 \\
\hline $01 / 06 / 13$ & 141.24 & 419.72 & 47.88 & 93.83 \\
\hline $01 / 12 / 13$ & 109.20 & 0 & 48.02 & 0 \\
\hline $01 / 20 / 13$ & 0 & 115.64 & 0 & 30.01 \\
\hline $01 / 27 / 13$ & 25.68 & 0 & 6.68 & 15.69 \\
\hline $02 / 03 / 13$ & 55.85 & 32.33 & 62.81 & 27.25 \\
\hline $02 / 10 / 13$ & 24.57 & 47.60 & 0 & 0 \\
\hline $02 / 17 / 13$ & 37.58 & 39.44 & 91.46 & 0 \\
\hline $02 / 24 / 13$ & 0 & 44.33 & 0 & 112.15 \\
\hline 03/03/13 & 141.60 & 64.79 & 353.43 & 154.91 \\
\hline $03 / 10 / 13$ & 73.87 & 0 & 212.61 & 86.07 \\
\hline Average & $50.86 \pm 54.05$ & $77.24 \pm 115.58$ & $68.96 \pm 108.72$ & $49.37 \pm 50.68$ \\
\hline $12 / 30 / 13$ & 0 & 693.36 & 0 & 0 \\
\hline 01/06/14 & 9.25 & 0 & 14.65 & 0 \\
\hline $01 / 13 / 14$ & 0 & 6.27 & 0 & 7.53 \\
\hline $01 / 20 / 14$ & 0 & 3.05 & 2.15 & 0 \\
\hline $01 / 27 / 14$ & 2.11 & 0 & 0 & 0 \\
\hline $02 / 03 / 14$ & 50.33 & 0 & 25.30 & 13.64 \\
\hline $02 / 10 / 14$ & 17.25 & 9.21 & 1.57 & 33.22 \\
\hline $02 / 17 / 14$ & 0 & 9.71 & 5.37 & 0 \\
\hline $02 / 24 / 14$ & 183.91 & 0 & 0 & 0 \\
\hline $03 / 03 / 14$ & 0 & 0 & 0 & 92.09 \\
\hline 03/10/14 & 92.84 & 0 & 3.80 & 57.71 \\
\hline Average & $32.34 \pm 58.19$ & $65.60 \pm 208.24$ & $4.80 \pm 8.07$ & $18.56 \pm 30.61$ \\
\hline
\end{tabular}

phytoflagellate abundances. In winter 2013, an aver-

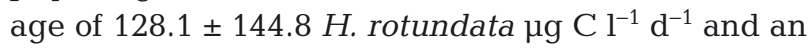
average of $118.3 \pm 146.4$ cryptophytes $\mu g \mathrm{C} \mathrm{l}^{-1} \mathrm{~d}^{-1}$ were removed by grazers (Table 2 ). An average of $66.7 \%$ of $H$. rotundata standing stock was removed from grazing, $30.3 \%$ by copepods and $36.4 \%$ by microzooplankton. An average of $35.5 \%$ of cryptophyte standing stock was removed from grazing, $18.2 \%$ by copepods and $17.3 \%$ by microzooplankton.

Similar to 2013, the amount of specific prey removed by different grazers in 2014 varied from week to week (Table 2). An average of $97.9 \pm 205.2$ H. rotundata $\mu \mathrm{g} \mathrm{Cl}^{-1} \mathrm{~d}^{-1}$ and $23.4 \pm 30.5$ cryptophytes $\mu \mathrm{g} \mathrm{C}$ $\mathrm{l}^{-1} \mathrm{~d}^{-1}$ were removed by grazers in the 2014 winter (Table 2). A higher concentration of $H$. rotundata than cryptophytes was removed by grazers, but a smaller percentage of $H$. rotundata standing stock was removed by grazers compared to cryptophytes (Fig. $3 \mathrm{~b}, \mathrm{~d}$ ). On average, copepods removed $5 \%$ and microzooplankton removed $17 \%$ of $H$. rotundata daily standing stock, for a total of $22 \%$. A smaller percentage of $H$. rotundata standing stock was removed compared to 2013, despite no difference in concentration of carbon removed by grazers between the 2 years (Table 2). Copepods removed an average of $7 \%$ of cryptophyte daily standing stock and microzooplankton removed $21 \%$, for a total of $28 \%$ cryptophytes removed by grazers (Fig. 3d). A similar percentage of cryptophyte standing stock was removed by grazers in 2013, although a higher concentration of cryptophyte carbon was removed by grazers in 2013 than 2014.

\section{Consumption of primary production by copepods and microzooplankton}

We compared how much carbon from $H$. rotundata and cryptophytes was consumed daily by microzooplankton and copepods to how much carbon was produced daily by gross primary production (GPP) (Fig. 4). Similar average rates of GPP occurred between the 2 years, but a smaller percentage of surface GPP was removed by zooplankton grazers in 2014 compared to 2013. The average estimated gross surface primary production in winter 2013 was $0.268 \pm 0.215 \mathrm{~g} \mathrm{C} \mathrm{m}^{-3} \mathrm{~d}^{-1}$ and $0.288 \pm 0.299 \mathrm{~g} \mathrm{C} \mathrm{m}^{-3} \mathrm{~d}^{-1}$ in 2014. In 2013, grazers removed at least $0.246 \pm 0.231 \mathrm{~g} \mathrm{C} \mathrm{m}^{-3} \mathrm{~d}^{-1}$ of the estimated gross daily primary production for the entire winter, which accounts for an average of $91 \%$ of the GPP. In 2014, grazers removed $0.121 \pm 0.199 \mathrm{~g} \mathrm{C} \mathrm{m}^{-3}$ $\mathrm{d}^{-1}$ of average gross daily primary production over the winter, which was an average of $42 \%$ of the GPP.

\section{DISCUSSION}

A bloom formed in winter 2014 but not in winter 2013, not because the GPP was higher in 2014 but because grazing was lower. The average amount of carbon removed by copepods and microzooplankton grazing on Heterocapsa rotundata and cryptophytes was similar to the estimated amount of carbon produced by gross daily primary production during winter 2013. In winter 2014, grazers removed substan- 

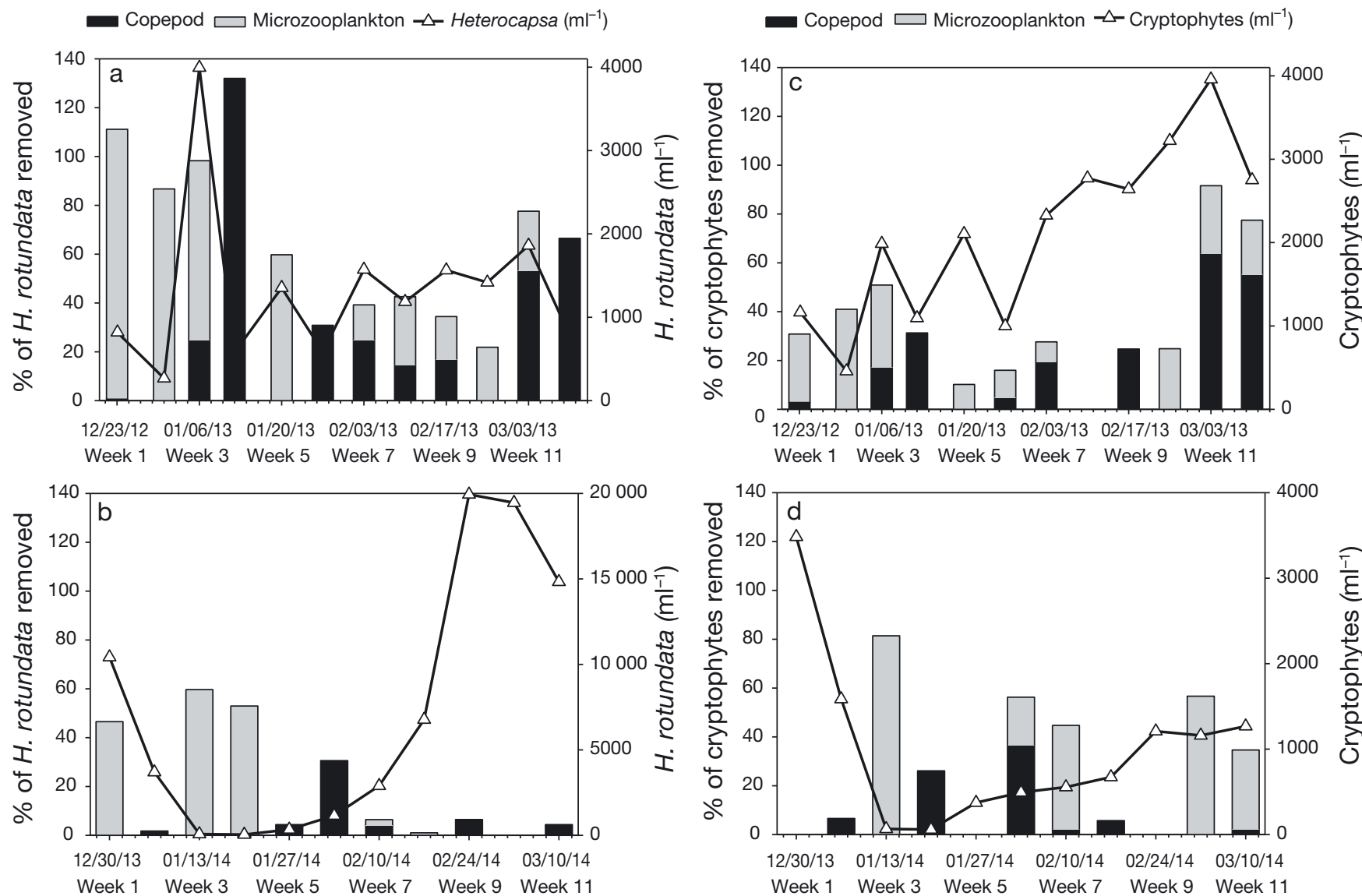

Fig. 3. Comparison of the abundance of phytoplankton species (cells ml ${ }^{-1}$ ) to the percentage standing stock of that species removed by copepods and microzooplankton ingestion. (a) Heterocapsa rotundata 2013; (b) H. rotundata 2014; (c) cryptophytes 2013; and (d) cryptophytes 2014. Note difference in right $y$-axis in b. Dates given as mm/dd/yy

tially less carbon than was produced by daily gross primary production; as a result, the standing stock of the phytoplankton community reached higher concentrations compared to 2013. The decrease in grazing pressure in late winter 2014 played a large role in achieving high abundances of $H$. rotundata by the end of winter. As observed by Sellner et al. (1991), grazing played a large role in controlling the winter standing stock of $H$. rotundata.

We substituted GPP for growth rates, as Behrenfeld (2010) did, because our method for measuring GPP was more precise than that for measuring growth rates; the change in $\mathrm{O}_{2}$ as measured with the $\mathrm{O}_{2}$ :Ar ratio was less variable than our estimated growth rates from the dilution experiments. GPP estimates only the amount of new carbon added by the total photosynthesizing community and not individual phytoplankton species. However, H. rotundata and cryptophytes accounted for at least $50 \%$ of the total chlorophyll $a$ in 15 of the 23 samples. We used GPP as a proxy for $H$. rotundata or cryptophyte growth rates, assuming their growth accounted for the majority of primary productivity we measured. Indeed, for winter 2014, H. rotundata abundance strongly correlates with primary production.

We used the canonical value of 50 as the C:chl a ratio (Strickland 1965) to convert between our measured chlorophyll a concentration to carbon concentration; however, this ratio is highly variable depending on the environment, season, and phytoplankton community composition (Sathyendranath et al. 2009). If the actual ratio is lower or higher than 50, then we will have overestimated or underestimated, respectively, the contribution of $H$. rotundata and cryptophytes to the total phytoplankton biomass. The combined biomass of cryptophytes and H. rotundata - estimated from our cell counts, measurements of cell size, and published carbon: volume relationships - was higher than total phytoplankton biomass estimated from chlorophyll a for 2 weeks out of 23, suggesting that we may have underestimated the total phytoplankton biomass for those 2 weeks. 

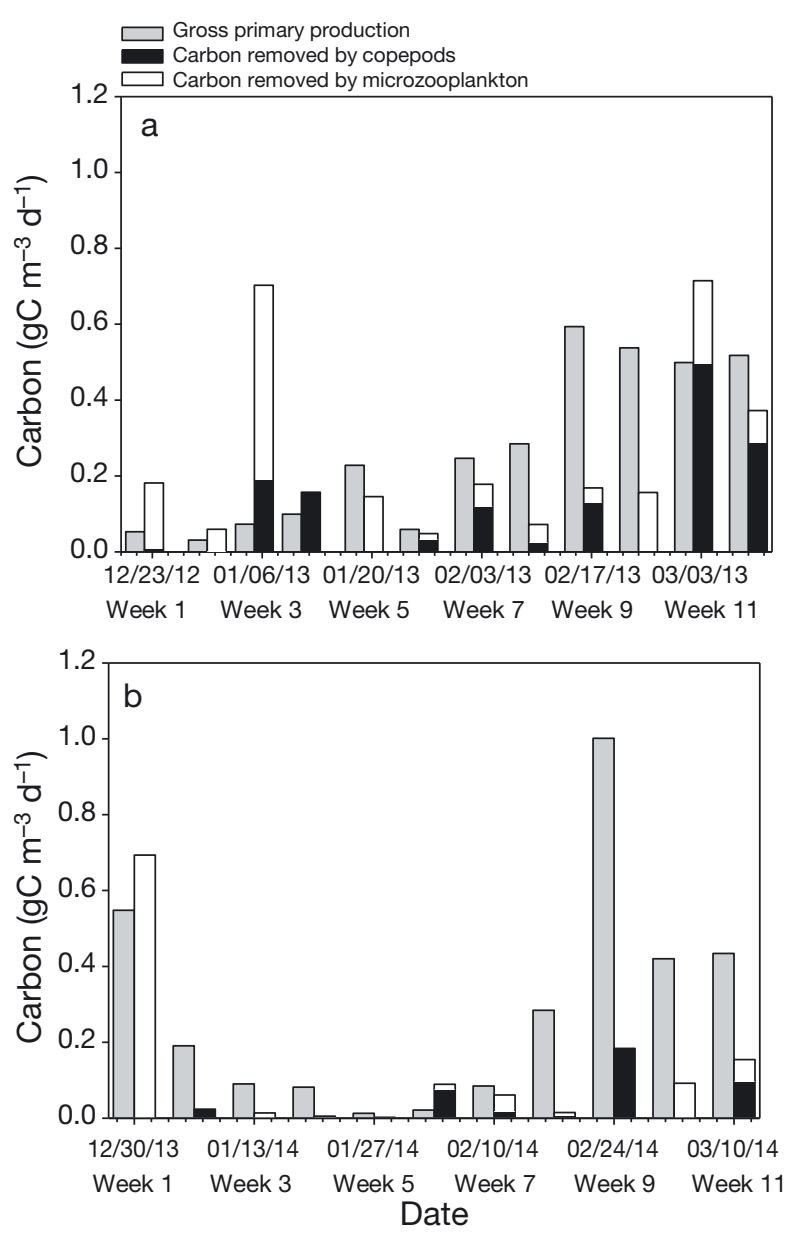

Fig. 4. Comparison of the estimated amount of gross carbon produced per day to the estimated amount of carbon removed by copepod and microzooplankton consumption of Heterocapsa rotundata and cryptophytes in the surface water of the Choptank River, MD, in the winters of (a) 2013 and (b) 2014. Dates given as mm/dd/yy

For the past $30 \mathrm{yr}$, the dilution method has been the most common and effective way to measure in situ microzooplankton grazing rates on primary producers (Schmoker et al. 2013), though scientists continue to improve application of the method (Gallegos 1989, Dolan et al. 2000, Calbet et al. 2008, 2012, Latasa 2014). Average microzooplankton community grazing may be overestimated when negative and nonsignificant data points are removed from bulk analyses of the data (Latasa 2014). We included non-significant positive results but changed negative grazing rates to 0 in our mean analyses, which is consistent with previous work (Strom et al. 2001, Calbet \& Landry 2004, Sherr et al. 2009, Lawrence \& MendenDeuer 2012). The 2-point dilution method, which we used for our calculations of growth and grazing rate, provides a conservative estimate of microzooplankton grazing rates (Worden \& Binder 2003) that reduces the potential for overestimation of the microzooplankton community grazing rate coefficient. Recent research in Narragansett Bay successfully used dilution experiments in a similar approach to ours to measure microzooplankton community grazing rates on the phytoplankton community at a single station throughout the year (Lawrence \& Menden-Deuer 2012).

This study provides insight into what factors allow winter blooms to occur, but it does not address the full impact of winter blooms on the entire ecosystem, because our sampling was restricted to 1 station. Litaker et al (2002b) showed that winter blooms of Heterocapsa triquetra in North Carolina were patchy and usually confined to specific areas of the estuary. Sellner et al (1991) also found patchy $H$. rotundata blooms in the Paxtuent River, usually aggregated downriver of a steep salinity gradient. We conducted a $72 \mathrm{~h}$ experiment to examine the influence of tides on $H$. rotundata abundance every $3 \mathrm{~h}$ and found no relationship between tidal height and abundance (data not shown). To fully understand the impact of winter blooms, future research will need to explore the extent of these blooms and their overall productivity.

Our data show that higher abundances of $H$. rotundata occurred in winter 2014 than winter 2013, in part because grazers removed less of the standing stock in the later year. Mean grazer population size did not differ between years, but the temporal pattern of grazer abundances did, and average grazing rates were lower in winter 2014 than in 2013. In winter 2014 , the water temperature was below $1.0^{\circ} \mathrm{C}$ for $3 \mathrm{wk}$, which coincided with a decrease in microzooplankton and copepod abundances, and in their grazing pressure. An exponential increase in abundance of $H$. rotundata occurred during the period of low grazing. Grazing on cryptophytes was also reduced, but this group did not bloom. It is most likely that $H$. rotundata is adapted for high growth rates in winter but cryptophytes are not, thus allowing $H$. rotundata populations to increase faster than cryptophytes when grazing is reduced. $H$. rotundata is known to bloom in the winter (Cohen 1985, Sellner et al. 1991, Marshall et al. 2005, Seong et al. 2006), but there are no reports of cryptophytes forming a winter bloom.

Water temperatures below $1.0^{\circ} \mathrm{C}$ may have had a negative impact on zooplankton survival and grazing rates. The Chesapeake Bay is located in a temperate climate and experiences a wide range of temperatures annually, with an average water temperature of $15^{\circ} \mathrm{C}$ in the Choptank River and monthly means that 
range from a minimum of $3^{\circ} \mathrm{C}$ in January to a maximum of $28^{\circ} \mathrm{C}$ in July (Maryland Department of Natural Resources 2013). Zooplankton grazing rates are reduced under cold temperatures (Caron et al. 2000), and our observations at temperatures $<1.0^{\circ} \mathrm{C}$ suggest this may have had a negative impact on zooplankton. By the time zooplankton populations recovered following the anomalously cold weather, the $H$. rotundata population had reached bloom abundances, illustrating the complexities involved in bloom formation. Environmental conditions supporting phytoplankton growth are required, but low grazing pressure is also necessary for a bloom to initiate. The bloom we observed in winter 2014 may not have formed if the grazer population had recovered sooner, or if $H$. rotundata growth was slower and did not reach high abundances before recovery of the copepod population.

In winter 2014, the majority of fixed carbon produced was not consumed by zooplankton during the winter; however, the fate of that carbon is unclear. Litaker et al. (2002a) measured low zooplankton grazing rates on a $H$. triquetra bloom in the Newport River estuary and they proposed that production from the bloom was primarily recycled in the microbial loop. Yet it is possible that the phytoplankton carbon is consumed by zooplankton in the spring. In spring 2014, when water temperatures increased, the Eurytemora carolleeae populations increased (data not shown) and probably grazed the $H$. rotundata bloom. E. carolleeae peaks in abundance in late March and April in the Chesapeake Bay region (Kimmel \& Roman 2004, North \& Houde 2004, Martino \& Houde 2010). Wet winters have been shown to result in high abundances and wide distribution of the copepod E. carolleeae in spring in Chesapeake Bay (Kimmel et al. 2006). It is plausible that high copepod abundances in springs following wet winters can be partly attributed to the winter dinoflagellate blooms that occur in wet winters (Cohen 1985, Sellner et al. 1991) and persist into early spring, providing food for the copepods.

The link between $H$. rotundata and E. carolleeae in winter and early spring may be important in understanding variations in survival and growth of fish larvae in the Chesapeake estuary. High abundances and the timing of the peak abundance of E. carolleeae are correlated with striped bass Morone saxatalis larval recruitment in spring (Shoji et al 2005, Martino \& Houde 2010). Timing of the bloom, copepod population development, and fish spawning will all affect the trophic transfer between winter-spring dinoflagellate blooms and larval fish.
We suggest that a reassessment of the importance of winter dinoflagellate blooms in ecosystems, especially in estuarine and coastal areas, is warranted, particularly in regard to their effects on population dynamics of zooplankton and fish larvae in the following spring.

Acknowledgements. We thank J. Ohler at the Maryland Department of Natural Resources for permission to use the Bill Burton Fishing Pier for sampling. We thank L. Rechen, A. Weigel, C. Fitzgerald, and A. Maynard for their assistance in setting up and breaking down experiments, and analyzing data. Finally, we thank T. Kana for the use of his MIMS machine to measure $\mathrm{O}_{2}$ concentrations. N.C.M. received support from Maryland Sea Grant under award no. 07523941 from the National Oceanic and Atmospheric Administration, U.S. Department of Commerce, and a Horn Point Laboratory Fellowship. UMCES contribution 5048.

\section{LITERATURE CITED}

Alekseev VR, Souissi A (2011) A new species within the Eurytemora affinis complex (Copepoda: Calanoida) from the Atlantic coast of USA, with observations on eight morphologically different European populations. Zootaxa 2767:41-56

Arar EJ, Collins GB (1997) In vitro determination of chlorophyll $a$ and pheophytin $a$ in marine and freshwater algae by fluorescence. Method 445.0. National Exposure Research Laboratory, US Environmental Protection Agency, Cincinnati, OH

Behrenfeld MJ (2010) Abandoning Sverdrup's Critical Depth Hypothesis on phytoplankton blooms. Ecology 91:977-989

Calbet A, Landry MR (2004) Phytoplankton growth, microzooplankton grazing, and carbon cycling in marine systems. Limnol Oceanogr 49:51-57

Calbet A, Trepat I, Almeda R, Saló V and others (2008) Impact of micro- and nanograzers on phytoplankton assessed by standard and size-fractionated dilution grazing experiments. Aquat Microb Ecol 50:145-156

Calbet A, Martinez RA, Isari S, Zervoudaki S and others (2012) Effects of light availability on mixotrophy and microzooplankton grazing in an oligotrophic plankton food web: evidences from a mesocosm study in Eastern Mediterranean waters. J Exp Mar Biol Ecol 424-425: 66-77

Caron DA, Dennett MR, Lonsdale DJ, Moran DM, Shalapyonok L (2000) Microzooplankton herbivory in the Ross Sea, Antarctica. Deep-Sea Res Part II 47:3249-3272

Cohen RRH (1985) Physical processes and the ecology of a winter dinoflagellate bloom of Katodinium rotundatum. Mar Ecol Prog Ser 26:135-144

> Dolan JR, Gallegos CL, Moigis A (2000) Dilution effects on microzooplankton in dilution grazing experiments. Mar Ecol Prog Ser 200:127-139

Frost BW (1972) Effects of size and concentration of food particles on the feeding behavior of the marine planktonic copepod Calanus pacificus. Limnol Oceanogr 17: 805-815

> Gallegos CL (1989) Microzooplankton grazing on phytoplankton in the Rhode River, Maryland: nonlinear feeding kinetics. Mar Ecol Prog Ser 57:23-33 
Howarth RW, Michaels AF (2000) The measurement of primary production in aquatic ecosystems. In: Sala OE, Jackson RB, Mooney HA, Howarth RW (eds) Methods in ecosystem science. Springer-Verlag, New York, NY, p 72-85

Irigoien X, Flynn KJ, Harris RP (2005) Phytoplankton blooms: a 'loophole' in microzooplankton grazing impact? J Plankton Res 27:313-321

Kana TM, Darkangelo C, Hunt MD, Oldham JB, Bennett GE, Cornwell JC (1994) Membrane inlet mass spectrometer for rapid high-precision determination of $\mathrm{N}_{2}, \mathrm{O}_{2}$, and $\mathrm{Ar}$ in environmental water samples. Anal Chem 66: 4166-4170

Kimmel DG, Roman MR (2004) Long-term trends in mesozooplankton abundance in Chesapeake Bay, USA: influence of freshwater input. Mar Ecol Prog Ser 267:71-83

Kimmel DG, Miller WD, Roman MR (2006) Regional scale climate forcing of mesozooplankton dynamics in Chesapeake Bay. Estuaries Coasts 29:375-387

Landry MR, Hassett RP (1982) Estimating the grazing impact of marine micro-zooplankton. Mar Biol 67:283-288

> Latasa M (2014) Comment: A potential bias in the databases of phytoplankton growth and microzooplankton grazing rates because of the improper formulation of the null hypothesis in dilution experiments. Limnol Oceanogr 59: 1092-1094

> Lawrence C, Menden-Deuer S (2012) Drivers of protistan grazing pressure: seasonal signals of plankton community composition and environmental conditions. Mar Ecol Prog Ser 459:39-52

Lee DY, Keller DP, Crump BC, Hood RR (2012) Community metabolism and energy transfer in the Chesapeake Bay estuarine turbidity maximum. Mar Ecol Prog Ser 449:65-82

Litaker RW, Tester PA, Duke CS, Kenney BE, Pinckney JL, Ramus J (2002a) Seasonal niche strategy of the bloomforming dinoflagellate Heterocapsa triquetra. Mar Ecol Prog Ser 232:45-62

Litaker RW, Warner VE, Rhyne C, Duke CS, Kenney BE, Ramus J, Tester PA (2002b) Effect of diel and interday variations in light on the cell division pattern and in situ growth rates of the bloom-forming dinoflagellate Heterocapsa triquetra. Mar Ecol Prog Ser 232:63-74

Marshall HG, Burchardt L, Lacouture R (2005) A review of phytoplankton composition within Chesapeake Bay and its tidal estuaries. J Plankton Res 27:1083-1102

Martino EJ, Houde ED (2010) Recruitment of striped bass in Chesapeake Bay: spatial and temporal environmental variability and availability of zooplankton prey. Mar Ecol Prog Ser 409:213-228

Maryland Department of Natural Resources (2013) Eyes on the bay. Available at www.eyesonthebay.net (accessed

Editorial responsibility: Urania Christaki, Wimereux, France on 17 December 2014)

Menden-Deuer S, Lessard EJ (2000) Carbon to volume relationships for dinoflagellates, diatoms, and other protist plankton. Limnol Oceanogr 45:569-579

> North EW, Houde ED (2004) Distribution and transport of bay anchovy (Anchoa mitchilli) eggs and larvae in Chesapeake Bay. Estuar Coast Shelf Sci 60:409-429

Sathyendranath S, Stuart V, Nair A, Oka K and others (2009) Carbon-to-chlorophyll ratio and growth rate of phytoplankton in the sea. Mar Ecol Prog Ser 383:73-84

Schmoker C, Hernandez-Leon S, Calbet A (2013) Microzooplankton grazing in the oceans: impacts, data variability, knowledge gaps and future directions. J Plankton Res 35:691-706

Sellner KG, Lacouturea RV, Cibika SJ, Brindleyc A, Brownleea SG (1991) Importance of a winter dinoflagellatemicroflagellate bloom in the Patuxent River estuary. Estuar Coast Shelf Sci 32:27-42

> Seong KA, Jeong HJ, Kim S, Kim GH, Kang JH (2006) Bacterivory by co-occurring red-tide algae, heterotrophic nanoflagellates, and ciliates. Mar Ecol Prog Ser 322:85-97

Sherr EB, Sherr BF (1993) Preservation and storage of samples for enumeration of heterotrophic protists. In: Kemp PF, Sherr BF, Sherr EB, Cole JJ (eds) Aquatic microbial ecology. Lewis Publishers, Boca Raton, FL, p 207-212

Sherr EB, Sherr BF, Hartz AJ (2009) Microzooplankton grazing impact in the western Arctic Ocean. Deep-Sea Res Part II 56:1264-1273

Shoji J, North EW, Houde ED (2005) The feeding ecology of Morone americana larvae in the Chesapeake Bay estuarine turbidity maximum: the influence of physical conditions and prey concentrations. J Fish Biol 66:1328-1341

> Stoecker DK, Thessen AE, Gustafson DE (2008) 'Windows of opportunity' for dinoflagellate blooms: reduced microzooplankton net growth coupled to eutrophication. Harmful Algae 8:158-166

Strickland JDH (1965) Production of organic matter in the primary stages of the marine food web chain. In: Riley JP, Skirrow G (eds) Chemical oceanography, Vol 1. Academic Press, New York, NY, p 477-610

Strom SL, Fredrickson KA (2008) Intense stratification leads to phytoplankton nutrient limitation and reduced microzooplanton grazing in the southeastern Bering Sea. Deep-Sea Res II 55:1761-1774

Strom SL, Brainard MA, Holmes JL, Olson MB (2001) Phytoplankton blooms are strongly impacted by microzooplankton grazing in coastal North Pacific waters. Mar Biol 138:355-368

Worden AZ, Binder BJ (2003) Application of dilution experiments for measuring growth and mortality rates among Prochlorococcus and Synechococcus population in oligotrophic environments. Aquat Microb Ecol 30:159-174

Submitted: September 30, 2014; Accepted: June 6, 2015 Proofs received from author(s): July 19, 2015 